\title{
O ESPAÇO DA ARBITRAGEM NO BRASIL: NOTÁVEIS E EXPERTSEM BUSCA DE RECONHECIMENTO
}

\author{
Fabiano Engelmann
}

\begin{abstract}
RESUMO
O artigo expõe resultados de uma pesquisa sócio-política sobre a construção do espaço da arbitragem no Brasil. O argumento consiste em três pontos centrais. O primeiro privilegia a mobilização em torno da justiça arbitral como "causa política" que envolve advogados, professores e políticos vinculados às associações empresariais e institutos liberais e tem como principal resultado a concretização de um marco institucional para as práticas arbitrais, a Lei n. 9307 promulgada em 1996. Uma segunda dimensão focaliza os autores e publicações sobre arbitragem indicando a difusão de idéias e a especialização disciplinar ao longo da década de 2000. Na terceira parte, aborda-se o espaço dos árbitros no Rio Grande do Sul investigando-se as condicionantes de seu desenvolvimento. A pesquisa é de natureza qualitativa e privilegia diversas bases de dados, destacando-se publicações legais, jornalísticas e acadêmicas, currículos vitae e entrevistas semiestruturadas. Destaca-se como principal resultado a explicitação das dificuldades de legitimação deste modelo de mediação de conflitos frente ao sistema judicial estatal no caso estudado. $O$ artigo está organizado em três partes. Na primeira procura-se recompor elementos para compreensão da difusão do ideário arbitral no Brasil e da mobilização em torno da construção do marco institucional para sua prática. Na segunda, é analisado o espaço da produção intelectual em torno do tema e a difusão de bases doutrinárias para a construção do conhecimento nesse campo. Em um terceiro momento, analisase o perfil e as modalidades de atuação dos árbitros tendo-se por base as práticas de arbitragem no estado do Rio Grande do Sul.
\end{abstract}

PALAVRAS-CHAVE: arbitragem; justiça; Brasil.

\section{INTRODUÇÃO 1}

A difusão de idéias e a emergência de um espaço de práticas de arbitragem relativamente autônomo em relação ao sistema de justiça estatal está estreitamente relacionado à expansão da globalização econômica. Alavancado a partir de instituições e agentes que promovem um modelo de jurisdição imbricado ao mundo dos negócios

\footnotetext{
$1 \mathrm{O}$ texto é o resultado de um Projeto de Pesquisa mais amplo apoiado pelo Conselho Nacional de Desenvolvimento Científico e Tecnológico (CNPq), "Globalização e Rule of Law: as disputas em torno do sentido político do sistema judicial brasileiro nas décadas de 90 e 2000 " que contempla também a análise da expansão das grandes sociedades de advogados e dos movimentos "law \& economics" no Brasil (ver ENGELMANN, 2011). A construção do banco de dados referente à parte da arbitragem contou com a participação do Bolsista de Iniciação Científica (Ufrgs/ Propesq) Fernando Marcial Ricci Araújo. Gostaríamos de agradecer aos pareceristas da Revista de Sociologia e Politica pelos comentários feitos para este artigo.
}

entre empresas privadas, a análise desse fenômeno na diversidade dos espaços nacionais apresentase como um grande desafio para a análise política. Nesse sentido, o presente texto pretende contribuir para uma melhor compreensão da construção do espaço das práticas e difusão de doutrinas sobre arbitragem no contexto brasileiro das duas últimas décadas.

Diversos trabalhos propondo uma Sociologia Política das instituições ${ }^{2}$ têm buscado uma apreensão mais fina das variantes das transformações dos estados nacionais e de suas instituições frente à influência do campo econômico internacional. Para esses estudos, o

\footnotetext{
2 Ver especialmente as pesquisas desenvolvidas sobre as elites cosmopolitas, os movimentos "altermondialistas" e a emergência de modelos institucionais supranacionais (DEZALAY \& GARTH, 2002; 2010; AGRIKOLIANSKY \& SOMMIER, 2005; COMMAILLE, 2007; ROBERT \& VAUCHEZ, 2010).
}

Rev. Sociol. Polít., Curitiba, v. 20, n. 44, p. 155-176, nov. 2012 
foco principal é o papel de mediação desempenhado pelas diversas espécies de elites (políticas, burocráticas e jurídicas) e a relação que estabelecem com o espaço internacional na tentativa de reformar e redefinir as instituições ancoradas nacionalmente.

No caso da expansão da arbitragem (DEZALAY \& GARTH, 1996), posicionam como questão central a problemática da construção da legitimidade da ordem jurídica internacional vinculada aos negócios protagonizados pelas grandes empresas multinacionais. A difusão do ideário da superioridade das práticas da arbitragem como mais eficazes na solução de litígios comerciais do que a justiça estatal típica do Estado Nacional aparece como determinante.

Nesse sentido, os agentes desse processo assumem um papel chave incluindo segmentos que se posicionam em uma linha intermediária entre o campo jurídico e o espaço econômico. Conforme Dezalay e Garth (idem), lideranças empresariais cosmopolitas, advogados vinculados às grandes firmas norte-americanas, juristas "notáveis" especializados em direito internacional e demais "think thanks" investem na construção de uma nova doxa sobre o Direito. A crença compartilhada por esses agentes é baseada na adesão a uma comunidade epistêmica ${ }^{3}$ que combina uma ciência das instituições com a fé na eficiência dos mercados e a mobilização de conhecimentos derivados da "nova economia institucional". O eixo central desse discurso é o "ideal de uma justiça internacional privada" e a promoção da lex mercatoria.

Se no âmbito da União Européia, nos Estados Unidos e no espaço internacional do "business world" esse processo pode parecer bastante evidente, o mesmo já não se aplica a outras dinâmicas nacionais. A demonstração da penetração dessas idéias, seu uso por segmentos da elite social e sua capacidade de redefinir instituições arraigadas é bastante complexa. No caso do Brasil, país com tradição de domínio

\footnotetext{
3 A noção de "comunidade epistêmica" compreende a construção de consensos a respeito de determinadas tomadas de decisão política a partir da mobilização de conhecimentos científicos e da adesão de comunidades de especialistas. Para mais detalhes, ver Haas (1992).
}

político dos bacharéis em Direito ${ }^{4}$ e de construção de uma justiça estatal fortemente calcada no Direito codificado, a legitimação das práticas e idéias relacionadas à arbitragem envolve uma forte batalha política e simbólica. Mesmo com uma crescente internacionalização da economia, o sistema de justiça e advocacia resistem a processos que apontem para reformas que indiquem maior subordinação do direito à economia.

Esses embates podem ser apreendidos na análise das mobilizações em torno da criação da Lei da Arbitragem, no investimento na construção da expertise, assim como, nas dificuldades e no caráter incipiente do reconhecimento da prática arbitral no Brasil. Portanto, tal modelo de justiça aparece "em legitimação" visto que sua superioridade em relação à justiça estatal na decisão de conflitos negociais é pouco reconhecida tanto no espaço econômico quanto no espaço jurídico. Visando uma melhor compreensão do processo de construção do espaço da arbitragem, além da seção metodológica, apresentada a seguir, o presente trabalho está dividido em três partes.

$\mathrm{Na}$ primeira procura-se recompor elementos para compreensão da difusão do ideário arbitral no Brasil e da mobilização em torno da construção do marco institucional para sua prática. $\mathrm{Na}$ segunda, é analisado o espaço da produção intelectual em torno do tema e a difusão de bases doutrinárias para a construção do conhecimento nesse campo. Em um terceiro momento, analisase o perfil e as modalidades de atuação dos árbitros tendo-se por base as práticas de arbitragem no estado do Rio Grande do Sul.

\section{NOTAS SOBRE A CONSTRUÇÃO DOS DADOS DA PESQUISA}

O trabalho é construído a partir de pesquisa que tem por estratégia principal combinar uma análise objetivista com a perspectiva dos agentes. Em uma primeira fase, predominantemente “objetivista”, por meio da comparação sistemática dos trajetos universitários, profissionais, políticos e indicações biográficas gerais, busca-se identificar padrões de recursos e indicativos dos

\footnotetext{
4 Entre os estudos que destacam o peso da passagem por faculdades de Direito na coesão das elites políticas brasileiras ao longo do Império, ver Adorno (1988) e Carvalho (1996).
} 
princípios de estruturação do espaço da arbitragem no Brasil e, com mais profundidade, no Rio Grande do Sul. Uma segunda fase centra-se na análise qualitativa da produção intelectual e tomadas de posição pública dos agentes vinculados ao espaço estudado, tendo por foco a relação dessa dimensão "perspectivista" com os dados construídos e apreendidos na primeira parte.

Os procedimentos de pesquisa utilizados contemplaram diversas fontes. Foi realizada uma exploração ampla do universo da arbitragem no Brasil, a partir de busca na internet, para identificar as câmaras de arbitragem nacionais, as publicações existentes sobre o tema e os nomes de indivíduos vinculados a esse universo. Nessa etapa foi possível agrupar os perfis da produção brasileira de uma "doutrina" sobre arbitragem, assim como as modalidades de câmaras existentes, além da definição de uma população de árbitros para os quais se buscou, em uma segunda etapa, a construção de dados sobre as trajetórias acadêmicas, profissionais e políticas, na qual foi efetuada uma análise comparada das trajetórias dos árbitros visando identificar trajetos recorrentes que pudessem indicar tendências e capitais importantes.

As fontes privilegiadas, em um primeiro momento, foram fontes secundárias, revistas, e buscas em sites pela internet. Depois foram realizadas entrevistas com uma população selecionada de árbitros posicionados em instituições no Rio Grande do Sul. Para as entrevistas, utilizou-se de um questionário semiestruturado, visando maior homogeneidade nas informações.

Para a construção dos dados sobre os percursos dos segmentos analisados foram feitos quadros comparativos para as seguintes categorias: (i) formação acadêmica (títulos universitários nacionais); (ii) formação no exterior (títulos universitários e escolares); (iii) domínio de idioma estrangeiro; (iv) carreira profissional e política (ocupações, postos públicos ocupados, exercício de mandatos) e $(v)$ informações gerais indicativas de participações de ocupação de postos políticos ou em entidades. A comparação desses percursos permitiu relacioná-los com as posições ocupadas e fornecer indicações parciais sobre os recursos mobilizados pelos agentes pesquisados.

\section{A ARBITRAGEM COMO "CAUSA POLÍ- TICA"}

Os processos políticos que sucederam a redemocratização de países da América latina ensejaram a discussão em torno da reconstrução das instituições políticas e evidenciaram, tanto no debate político quanto no debate acadêmico, a tensão entre prescrições de modelos e tradições sócio-políticas específicas. Nesse contexto, um conjunto de proposições de reforma que contemplam o casamento entre a democracia, a racionalidade das instituições e sua afinidade com a ordem econômica tiveram uma larga difusão no contexto latino-americano ao longo das décadas de 1990 e 2000.

Destaca-se nesse contexto a doutrina do Rule of $L a w^{5}$ calcada especificamente em um ideário de "aproximação" do sistema judicial e da economia com a adequação dos ordenamentos jurídicos nacionais ao ambiente de negócios internacionalizado. Tal modelo obteve recepção em alguns países da América Latina, onde se destaca o Chile (DEZALAY \& GARTH, 2002), entretanto, no caso brasileiro, ele não logrou o mesmo impacto no processo de recomposição do sistema judicial que se iniciou em torno da Constituinte de 1986. A redefinição das funções políticas das instituições judiciais no Brasil posteriormente à redemocratização teve como centro o crescimento do Ministério Público e, especialmente, a afirmação do poder Judiciário como poder de Estado com grande intervenção na esfera pública.

É nessa conjuntura de grande ativismo políticojudicial nas décadas de 1990 e de 2000 que emerge a mobilização de lideranças empresariais e advogados em torno da promulgação de uma lei para as práticas de arbitragem. O resultado desse processo é a aprovação da Lei n. 9 307/96 e a criação de diversas câmaras especializadas na jurisdição de conflitos das relações negociais e exteriores ao sistema estatal. Também a partir dessa movimentação foram firmados convênios com o Banco Interamericano de Desenvolvimento (BID) que financiou a organização de cursos e seminários visando difundir a "cultura arbitral" no país (LIMA, 1997).

\footnotetext{
5 Uma discussão aprofundada sobre os preceitos da doutrina do Rule of Law e sua inserção nas estratégias norteamericanas de "exportação da democracia" pode ser encontrada em Trubek (2006).
} 
A primeira câmara de arbitragem com amplitude nacional, Câmara Brasileira de Mediação e Arbitragem Empresarial (Cbmae) foi criada a partir do modelo propagado pelo Banco Interamericano de Desenvolvimento (BID). Os convênios com o BID também apoiaram a criação de diversas câmaras estaduais vinculadas às associações comerciais e industriais locais. Os acordos possibilitaram a homogeneização de modelos de organização das câmaras com listas de árbitros e com a realização de cursos de treinamento em métodos de resolução de conflitos.

Acompanha esse fenômeno a proliferação de publicações especializadas que promovem o ideário americano do law \& economics no Brasil propugnando reformas e críticas à ineficiência das instituições judiciais ${ }^{6}$. No mesmo sentido, a explosão de litígios em que são colocadas em xeque as normatizações do mercado financeiro patrocinadas pelas grandes sociedades de advogados ${ }^{7}$ corroboram uma complexificação da disputa pelo sentido das definições de Direito e justiça ao longo das décadas de 1990 e 2000.

\section{III.1.A construção da Lei da Arbitragem: Uma causa de empresários, políticos e experts}

Desde o início da década de 1980, diversas iniciativas direcionaram a construção institucional da arbitragem no Brasil, passando por iniciativas oriundas do Ministério da Desburocratização (1976-1986), congressos, formulação de projetos de lei, o ativismo dos institutos liberais e diversas associações comerciais. Esse processo mostra a complexidade de estudar-se as bases de importação de um instituto já assimilado em sistemas judiciais como o norte-americano, e que envolve desde a mobilização de associações empresariais periféricas até a viabilização de acordos com organismos internacionais promotores da cultura da arbitragem. Da mesma forma, a concretização desse marco legal contempla a adesão de políticos vinculados ao meio empresarial que contribuem para alavancar a prática arbitral como "causa

\footnotetext{
6 Sobre a difusão do movimento doutrinário Law \& Economics no espaço dos juristas e dos economistas no Brasil ver Engelmann (2011).

7 Tomou-se como fonte o ranking com informações sobre a atuação das 450 maiores sociedades de advogados presente no anuário Análise Advocacia de 2007 (ANÁLISE EDITORIAL, 2007).
}

política". A presença de organismos internacionais como o Banco Mundial foi apenas parte de um processo que evolve um amplo leque de agentes posicionados no espaço de fronteira entre o Direito e a economia que compreende a adesão ao ideário liberal e o vínculo ao espaço empresarial.

A realização de um Congresso Internacional de Arbitragem no âmbito da Confederação Nacional do Comércio, em 1985 foi, conforme relata Muniz (2006), base para o início da movimentação de empresários e políticos denominada pelo autor de "operação Arbiter" e que viria a culminar com a aprovação no Congresso Nacional da "Lei da Arbitragem". Essa lei, na sua redação final, reproduz os princípios da "Lei Modelo" da arbitragem internacional da United Nations Commission on International Trade Law (Uncitral), de 1985. Tal organismo consultivo é vinculado à Organização das Nações Unidas (ONU) e tem por objetivo reformar e harmonizar os princípios de direito comercial em escala mundial.

Conforme relata Petrônio Muniz (idem), advogado vinculado ao Instituto Liberal de Pernambuco e liderança na mobilização, o início da "operação Arbiter" ocorre em reunião de empresários e advogados na Associação Comercial de Pernambuco, em abril de 1989, em conjunto com membros do Instituto Liberal do Estado. A partir dessa reunião, os "líderes pernambucanos", por meio da mediação do - à época - Senador do Partido da Frente Liberal (PFL), Marco Maciel, reúnem apoios a favor da redação e proposição de um Projeto de Lei. Dessa reunião, conforme Muniz (idem) surge a iniciativa de juntar-se com a Associação Comercial de São Paulo visando transformar o movimento pernambucano em um movimento nacional.

A partir da mobilização em um estado periférico, e com o apoio de um Senador que se torna "padrinho" do movimento, em novembro de 1991, ocorre em São Paulo o segundo evento considerado chave para concretizar uma base de adesões em torno da elaboração do Projeto de Lei de arbitragem. Essa reunião simboliza também a adição de grandes escritórios de advocacia paulista e professores da Faculdade de Direito da Universidade de São Paulo (USP) aos promotores da "causa". Participam Pedro Batista Martins, advogado empresarial, Ada Grinover, professora de Direito da USP, Selma Ferreira, advogada 
vinculada à Federação das Indústrias do Estado de São Paulo (Fiesp) e Carlos Alberto Carmona, advogado e professor da USP, juristas que se destacam na publicação de textos a favor da legitimação da prática arbitral no sistema de justiça brasileiro e também compõem a comissão redatora do anteprojeto da lei de arbitragem.
Os membros dessa primeira comissão destacam-se por sua multiposicionalidade, que une expertise jurídica e acadêmica - todos têm grande investimento em cursos de pós-graduação - com a presença em grandes escritórios de advocacia. Da mesma forma, a inserção associativa é bastante forte, além da produção intelectual na fronteira entre os temas do Direito e da Economia.

TABELA 1 - COMISSÃO QUE ELABOROU O ANTEPROJETO DA LEI DE ARBITRAGEM

\begin{tabular}{|c|c|c|c|}
\hline MEMBRO & LIVRO PUBLICADO & $\begin{array}{l}\text { TRAJETO ACADÊMICOE } \\
\text { PROFISSIONAL }\end{array}$ & OUTRAS INFORMAÇÕES \\
\hline \multirow{7}{*}{$\begin{array}{l}\text { Carlos } \\
\text { Alberto } \\
\text { Carmona }\end{array}$} & $\begin{array}{l}\text { Arbitragem e } \\
\text { Processo. }\end{array}$ & $\begin{array}{l}\text { - Graduação em Direito pela } \\
\text { USP (1976 - 1980); }\end{array}$ & $\begin{array}{l}\text { - Vice-Presidente do Instituto } \\
\text { Brasileiro de Direito Processual; }\end{array}$ \\
\hline & \multirow{6}{*}{$\begin{array}{l}\text { Um comentário a Lei } \\
\text { № 9307/96. São } \\
\text { Paulo: Atlas, } 2009 .\end{array}$} & $\begin{array}{l}\text { - Doutorado em Direito pela } \\
\text { USP (1991); }\end{array}$ & $\begin{array}{l}\text { - Membro do Instituto Ibero- } \\
\text { Americano de Direito Processual; }\end{array}$ \\
\hline & & $\begin{array}{l}\text { - Advogado da Marques } \\
\text { Rosado Toledo Cesar \& } \\
\text { Carmona Advogados; }\end{array}$ & $\begin{array}{l}\text { - Membro do International } \\
\text { Association of Procedural Law e } \\
\text { International Law Association; }\end{array}$ \\
\hline & & - Professor Titular da USP; & $\begin{array}{l}\text { - Membro efetivo do Instituto } \\
\text { Brasileiro de Direito Processual; }\end{array}$ \\
\hline & & $\begin{array}{l}\text { - Professor da Universidade } \\
\text { Presbiteriana Mackenzie (até } \\
\text { 2006); }\end{array}$ & $\begin{array}{l}\text { - Membro do Instituto Ibero- } \\
\text { Americano de Direito Processual; }\end{array}$ \\
\hline & & & $\begin{array}{l}\text { - Membro da International } \\
\text { Association of Procedural Law; }\end{array}$ \\
\hline & & & $\begin{array}{l}\text { - Membro do Conselho } \\
\text { Consultivo Tribunal Arbitral do } \\
\text { Comércio. }\end{array}$ \\
\hline \multirow[t]{8}{*}{$\begin{array}{l}\text { Pedro } \\
\text { Batista } \\
\text { Martins }\end{array}$} & \multirow{8}{*}{$\begin{array}{l}\text { "Apontamentos sobre a } \\
\text { Lei de Arbitragem". } \\
\text { São Paulo: Forense, } \\
2008 .\end{array}$} & $\begin{array}{l}\text { - Graduação em Direito } \\
\text { pela Universidade Estadual do } \\
\text { Rio de Janeiro (UERJ) (1978); }\end{array}$ & $\begin{array}{l}\text { - Árbitro do Centro de } \\
\text { Conciliación y Arbitraje para el } \\
\text { Mercosur; }\end{array}$ \\
\hline & & $\begin{array}{l}\text { - Especialização em Direito da } \\
\text { Economia pelo Instituto de } \\
\text { Estudos de Direito da } \\
\text { Economia (1983): }\end{array}$ & $\begin{array}{l}\text { - Árbitro da Câmara Portuguesa } \\
\text { de Comércio no Brasil São } \\
\text { Paulo; }\end{array}$ \\
\hline & & \multirow{2}{*}{$\begin{array}{l}\text { - Especialização no American } \\
\text { and International Law and } \\
\text { Comparative Law Center } \\
\text { (1989); }\end{array}$} & $\begin{array}{l}\text { - Membro do Comitê Executivo } \\
\text { pela Swiss Arbitration Academy } \\
\text { (SAA); }\end{array}$ \\
\hline & & & $\begin{array}{l}\text { - Árbitro da Cámara Argentina de } \\
\text { Comercio (Cermarc); }\end{array}$ \\
\hline & & $\begin{array}{l}\text { - Doutorado em andamento em } \\
\text { Direito pela Universidad San } \\
\text { Pablo, Madrid (2005); }\end{array}$ & $\begin{array}{l}\text { - Árbitro da Câmara de Mediação } \\
\text { e Arbitragem das Eurocâmaras } \\
\text { (CAE); }\end{array}$ \\
\hline & & \multirow[t]{3}{*}{$\begin{array}{l}\text { - Advogado-sócio na Batista } \\
\text { Martins Advogados. }\end{array}$} & $\begin{array}{l}\text { - Membro do Comitê Consultivo } \\
\text { Brasileiro da International Centre } \\
\text { for Dispute Resolution (ICDR), } \\
\text { Estados Unidos; }\end{array}$ \\
\hline & & & $\begin{array}{l}\text { - Árbitro da Câmara de Comércio } \\
\text { Argentino Brasileira de São } \\
\text { Paulo (Camarbra); }\end{array}$ \\
\hline & & & $\begin{array}{l}\text { - Fundador do conselho assessor } \\
\text { Comité Argentino de Arbitraje } \\
\text { Nacional y Transnacional (Carat), } \\
\text { Argentina. }\end{array}$ \\
\hline
\end{tabular}




\begin{tabular}{|c|c|c|c|}
\hline \multirow[t]{16}{*}{$\begin{array}{l}\text { Selma } \\
\text { Ferreira } \\
\text { Lemes }\end{array}$} & \multirow{5}{*}{$\begin{array}{l}\text { "Arbitragem: estudos } \\
\text { em homenagem ao } \\
\text { Prof. Guido Fernando } \\
\text { da Silva Soares". São } \\
\text { Paulo: Atlas, 2001; } \\
\text { "Árbitro: princípios da } \\
\text { independência e da } \\
\text { imparcialidade". São } \\
\text { Paulo: LTr, 2001. } \\
\text { "Arbitragem na } \\
\text { Administração Pública. } \\
\text { Fundamentos jurídicos } \\
\text { e eficiência econômica. } \\
\text { São Paulo: Quartier } \\
\text { Latin, 2007. }\end{array}$} & $\begin{array}{l}\text { - Mestrado em Direito pela } \\
\text { USP (2000); }\end{array}$ & $\begin{array}{l}\text { - Advogada Sócia Titular da } \\
\text { Selma Lemes Advogados } \\
\text { Associados, atuando na } \\
\text { consultoria em arbitragem; }\end{array}$ \\
\hline & & \multirow{6}{*}{$\begin{array}{l}\text { - "Arbitrator's Practice", curso } \\
\text { ministrado pelo Arbitration and } \\
\text { Mediation Center (WIPO), } \\
\text { World Intellectual Property } \\
\text { Organization, Genebra, 1997; } \\
\text { - Doutorado em Integração da } \\
\text { América Latina pela } \\
\text { USP/Prolam (2005); } \\
\text { - Advogada } \\
\text { - Professora de Arbitragem do } \\
\text { curso de Graduação da Escola } \\
\text { de Direito de São Paulo da } \\
\text { Fundação Getúlio Vargas } \\
\text { (FGV); }\end{array}$} & \multirow{5}{*}{$\begin{array}{l}\text { - Estágio na Corte de Arbitragem } \\
\text { na Corte Internacional de } \\
\text { Comércio, Paris (1990); } \\
\text { - Assessora do Ministério da } \\
\text { Justiça na Reunião de Ministros } \\
\text { da Justiça do Mercado Comum } \\
\text { do Sul (Mercosul) para a } \\
\text { elaboração da Convenção } \\
\text { Internacional de Arbitragem } \\
\text { Comercial Privada do Mercosul, } \\
\text { firmada em Buenos Aires em } \\
1998 \text { (18 meses); }\end{array}$} \\
\hline & & & \\
\hline & & & \\
\hline & & & \\
\hline & \multirow{11}{*}{$\begin{array}{l}\text { "Aspectos } \\
\text { Fundamentais da Lei } \\
\text { de Arbitragem". Rio de } \\
\text { Janeiro: Forense, } \\
\text { 1999. }\end{array}$} & & \\
\hline & & & \multirow{2}{*}{$\begin{array}{l}\text { - Coordenadora e Professora do } \\
\text { Curso de Arbitragem do } \\
\text { Programa de Educação } \\
\text { Continuada da Fundação Getúlio } \\
\text { Vargas - (Gvlaw-FGV) em São } \\
\text { Paulo e Rio de Janeiro; }\end{array}$} \\
\hline & & \multirow{9}{*}{$\begin{array}{l}\text { - Professora e Coordenadora } \\
\text { do Curso de Arbitragem no } \\
\text { Programa de Pós-Graduação } \\
\text { em Educação Continuada } \\
\text { (Gvlaw) da Escola de Direito } \\
\text { de São Paulo da Fundação } \\
\text { Getúlio Vargas - (Edesp-FGV); }\end{array}$} & \\
\hline & & & $\begin{array}{l}\text { - Membro do Grupo Latino- } \\
\text { Americano da Corte Internacional } \\
\text { de Arbitragem da Câmara de } \\
\text { Comércio Internacional (CCl) } \\
\text { Paris; }\end{array}$ \\
\hline & & & $\begin{array}{l}\text { - Vice-Presidente do Comitê } \\
\text { Gestor do Centro de Arbitragem } \\
\text { da Câmara Americana de São } \\
\text { Paulo (Amcham); }\end{array}$ \\
\hline & & & $\begin{array}{l}\text { - Integra o Corpo de Árbitros de } \\
\text { diversas Instituições Arbitrais no } \\
\text { Brasil e, no Chile, na Câmara de } \\
\text { Arbitragem de Santiago; }\end{array}$ \\
\hline & & & $\begin{array}{l}\text { - Atua como consultora em } \\
\text { arbitragens nacionais e } \\
\text { internacionais, inclusive como } \\
\text { "expert witness" em Direito } \\
\text { Brasileiro; }\end{array}$ \\
\hline & & & $\begin{array}{l}\text { - Árbitra Presidente de tribunais } \\
\text { arbitrais no Brasil; }\end{array}$ \\
\hline & & & $\begin{array}{l}\text { - Diretora da Câmara de } \\
\text { Mediação e Arbitragem de São } \\
\text { Paulo do Centro e Federação } \\
\text { das Indústrias do Estado de São } \\
\text { Paulo (Ciesp-Fiesp) (1995 - } \\
\text { 2002); }\end{array}$ \\
\hline & & & $\begin{array}{l}\text { - Representante do Brasil na } \\
\text { Corte Internacional de } \\
\text { Arbitragem da Câmara de } \\
\text { Comércio Internacional (CCl), } \\
\text { Paris, com mandato de três } \\
\text { anos; }\end{array}$ \\
\hline & & & $\begin{array}{l}\text { - Membro do Corpo de Árbitros } \\
\text { da Câmara de Arbitragem do } \\
\text { Mercado da Bolsa de Mercados } \\
\text { e Futuros da Bolsa de Valores de } \\
\text { São Paulo (BM\&F-Bovespa); }\end{array}$ \\
\hline
\end{tabular}




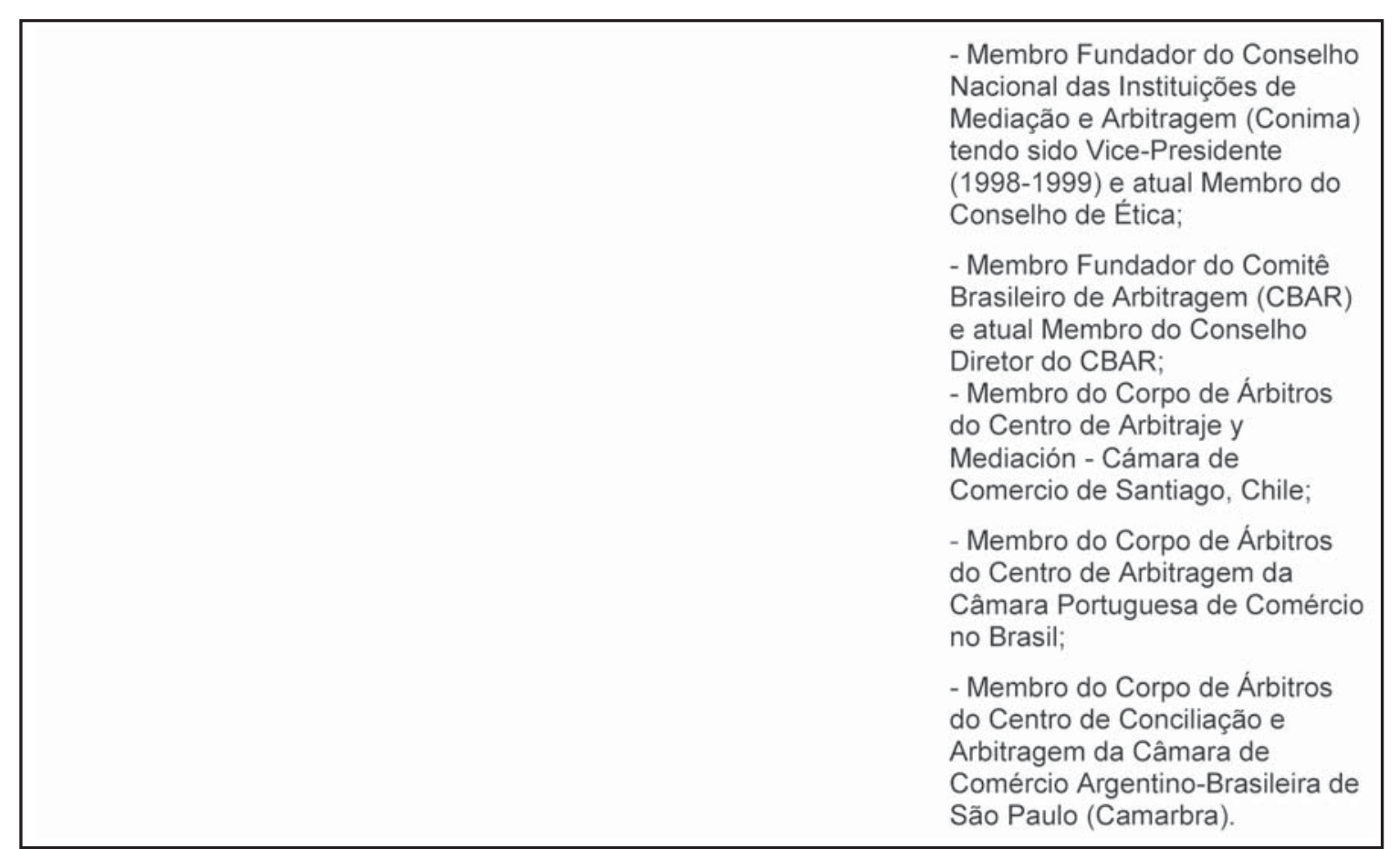

FONTE: Currículos vitae registros na plataforma lattes, consultados em 18 de agosto de 2010; Engelmann (2010).

A discussão do conteúdo do anteprojeto de Lei elaborado pela comissão foi objeto ainda de uma terceira reunião mencionada em Muniz (2006) sobre a "Operação Arbiter", um Seminário Nacional de Arbitragem realizado em Curitiba, "Organizado pela Coordenação Nacional da Operação Arbiter com o apoio do Instituto Liberal do Paraná. Reuniram-se mais de 300 pessoas, entre advogados, magistrados, promotores públicos, professores, acadêmicos, empresários e profissionais liberais. Ao fim do evento foi aprovado por aclamação o anteprojeto redigido por Carlos Carmona, Selma Lemes e Pedro Baptista Martins. Entidades apoiadoras: Conselho Nacional das Associações Comerciais, Associação Comercial de São Paulo, Instituto Brasileiro de Direito Processual, Centro Brasileiro de Arbitragem, Comissão de Arbitragem da Câmara de Comércio Brasil/Canadá, Prodex - Associação de Desenvolvimento Executivo, Câmara Internacional de Comércio do Brasil, Associação Alumini da América do Sul da Academy of America and International Law da América do Sul, Federação das Indústrias de São Paulo, Centro das Indústrias de São Paulo, Banco Bamerindus do Brasil S.A, Associação Brasileira de Shopping Centers, Ordem dos Advogados do Brasil-Seccional Pernambuco" (idem, p. 80).
Além dos apoios mobilizados junto a organizações que compõem o espaço de formulação de idéias, tais como institutos liberais e associações e federações empresariais, ao longo do ano de 1995 começam a ser fundadas diversas comissões de arbitragem. Estas são vinculadas às associações comerciais e industriais estaduais e visam já projetar a concretização de câmaras arbitrais.

O debate legislativo sobre o tema ocorre ao longo de 1995 e 1996. Divide-se no Congresso um pólo vinculado predominantemente ao Partido da Social-Democracia Brasileira (PSDB) e PFL, capitaneado por Marco Maciel, então VicePresidente da República, e outro composto pela oposição liderada por deputados do Partido dos Tabalhadores (PT) e do Partido Comunista do Brasil (PCdoB). O anteprojeto recebeu 12 propostas de emendas. A principal divisão nas tomadas de posição pública deu-se entre uma tendência mais "estatista", representada pelas emendas apostas pelo PT por meio do Deputado Federal e advogado de Santa Catarina, Milton Mendes e o projeto "liberal" que fundamentava a proposta de lei original.

A mobilização contrária às emendas sugeridas pelo PT que visavam maior subordinação das 
práticas de arbitragem à jurisdição estatal foi dirigida pelos interlocutores do empresariado no Congresso, contatados pelas associações empresariais estaduais e nacionais. A rejeição às emendas predominou tanto no parecer do Relator, Celso Russomano, Deputado Federal pelo PFL quanto, posteriormente, no plenário da Câmara.

Um dos grandes atores "externos" foi a Confederação das Associações Comerciais e Empresariais do Brasil (presidida no período por Guilherme Afif Domingos - filiado ao PFL) que mobilizou deputados ligados às diversas Federações Estaduais Comerciais para pressionarem parlamentares a rejeitar as emendas ao texto original da Lei da Arbitragem. Entre as propostas apresentadas pelo Deputado Federal Milton Mendes, do PT, que evidenciavam a disputa entre a jurisdição estatal e o modelo de "justiça privada", pode-se destacar a proposta de substituição do termo "Sentença Arbitral" pela expressão "Laudo Arbitral”, a supressão do artigo que vedaria o recurso da decisão dos árbitros ao poder Judiciário e a equiparação da decisão do árbitro à decisão de magistrados. A Tabela 2, a seguir, é ilustrativa dos principais argumentos mobilizados no debate.

TABELA2 -ARGUMENTOS MOBILIZADOS NO TRÂMITE DO PROJETO DE LEI NA CÂMARA(OUTUBRO DE 1995-JUNHO 1996)

\begin{tabular}{|c|c|c|c|}
\hline DEPUTADO & PARTIDO & TEXTO DA EMENDA & $\begin{array}{l}\text { JUSTIFICATIVADAEMENDA-ARGUMENTOS } \\
\text { MOBILIZADOS }\end{array}$ \\
\hline $\begin{array}{l}\text { Milton } \\
\text { Mendes }\end{array}$ & PT-SC & $\begin{array}{l}\text { 1) Emenda } \\
\text { Substitutiva: } \\
\text { "Substitua-se, em } \\
\text { todos os dispositivos } \\
\text { do projeto o termo } \\
\text { sentença arbitral pela } \\
\text { expressão laudo } \\
\text { arbitral". }\end{array}$ & $\begin{array}{l}\text { "A redação original, ao denominar a decisão } \\
\text { arbitral como 'sentença', o fez na intenção de } \\
\text { equipará-la às decisões do poder Judiciário. } \\
\text { Tanto que nos artigos } 18 \text { e } 31 \text { da proposta, } \\
\text { determina-se que os efeitos da 'sentença } \\
\text { arbitral' sejam os mesmos da 'sentença } \\
\text { judicial'. Ocorre que a arbitragem não faz } \\
\text { parte nem é órgão do poder Judiciário. } \\
\text { Destarte, suas decisões não podem ter os } \\
\text { mesmos efeitos das sentenças judiciais". }\end{array}$ \\
\hline \multirow[t]{2}{*}{$\begin{array}{l}\text { Milton } \\
\text { Mendes }\end{array}$} & PT-SC & $\begin{array}{l}\text { 4) Emenda } \\
\text { Supressiva: Suprima- } \\
\text { se artigo } 18 \text { do } \\
\text { projeto. }\end{array}$ & $\begin{array}{l}\text { O dispositivo proposto é flagrantemente } \\
\text { inconstitucional, haja vista que "a lei não } \\
\text { excluirá da apreciação do poder Judiciário } \\
\text { lesão ou ameaça a direito". Assim, o artigo } \\
\text { deve ser suprimido, posto que veda recurso } \\
\text { ao poder Judiciário da chamada sentença } \\
\text { arbitral e não submete a decisão arbitral à } \\
\text { homologação pelo poder Judiciário. Por } \\
\text { outro lado, o juizo arbitral não encontra } \\
\text { previsão na Constituição Federal, não } \\
\text { podendo ser considerado seus membros - } \\
\text { os árbitros como juízes "de direito". }\end{array}$ \\
\hline & & $\begin{array}{l}\text { 5) Emenda } \\
\text { Modificativa: Dê-se ao } \\
\text { artigo } 31 \text {, a seguinte } \\
\text { redação: "O laudo } \\
\text { arbitral, depois de } \\
\text { homologado, produz }\end{array}$ & $\begin{array}{l}\text { Inconstitucionalidade da decisão arbitral ter } \\
\text { os mesmos efeitos da sentença proferida }\end{array}$ \\
\hline
\end{tabular}




\begin{tabular}{|c|c|c|c|}
\hline $\begin{array}{l}\text { Milton } \\
\text { Mendes }\end{array}$ & PT-SC & $\begin{array}{l}\text { entre as partes e seus } \\
\text { sucessores os } \\
\text { mesmos efeitos da } \\
\text { sentença judiciária; e } \\
\text { contendo condenação } \\
\text { da parte, a } \\
\text { homologação Ihe } \\
\text { confere eficácia de } \\
\text { título executivo". }\end{array}$ & $\begin{array}{l}\text { pelos órgãos do poder Judiciário. } \\
\text { "Estaríamos criando em lei ordinária uma } \\
\text { instância decisória com poderes } \\
\text { equivalentes aos do Judiciário, mas sem } \\
\text { nenhuma previsão ou autorização } \\
\text { constitucional a fundamentá-la". }\end{array}$ \\
\hline $\begin{array}{l}\text { Milton } \\
\text { Mendes }\end{array}$ & PT-SC & $\begin{array}{l}\text { 9) Emenda } \\
\text { Supressiva: Suprima- } \\
\text { se do artigo } 44 \text { do } \\
\text { projeto, as seguintes } \\
\text { expressões: "os } \\
\text { artigos } 101 \text { e o inciso } \\
\text { VII do artigo } 51 \text { da Lei } \\
\text { n. } 8078 \text {, de } 11 \text { de } \\
\text { agosto de } 1990 \text {, } \\
\text { Código de Defesa do } \\
\text { Consumidor". }\end{array}$ & $\begin{array}{l}\text { "O artigo } 101 \text { do Código de Processo Civil } \\
\text { que se pretende revogar no artigo } 44 \text { deve } \\
\text { ser mantido em vigor, haja vista estabelecer } \\
\text { a competência do juízo que irá homologar o } \\
\text { laudo arbitral, a fim de compatibilizar-se com } \\
\text { emendas outras por nós apresentada, que } \\
\text { mantém a necessidade de homologação de } \\
\text { decisão arbitral. } \\
\text { Já o inciso VIII, do artigo 51, da Lei n. } 8078 \\
\text { - Código de Defesa do Consumidor - deve } \\
\text { continuar em vigor, a fim de que a } \\
\text { arbitragem não venha ser usada na solução } \\
\text { de litígios decorrentes daquela Lei Única } \\
\text { aprovada". }\end{array}$ \\
\hline \multirow{3}{*}{$\begin{array}{l}\text { Aldo } \\
\text { Arantes }\end{array}$} & \multirow{3}{*}{$\begin{array}{l}\text { PCdoB- } \\
\text { GO }\end{array}$} & \multirow{3}{*}{$\begin{array}{l}\text { 12) Emenda } \\
\text { Supressiva: Suprima- } \\
\text { se o artigo } 34 \text { bem } \\
\text { como, na parte final } \\
\text { do } 2 \text { inciso do artigo } 2 \\
\text { a expressão "[...] } \\
\text { regras internacionais } \\
\text { de comércio". }\end{array}$} & $\begin{array}{l}\text { "A formulação do artigo } 34 \text { do Projeto de Lei } \\
\text { prevê: 'A sentença estrangeira será } \\
\text { reconhecida ou executada no Brasil de } \\
\text { conformidade com os tratados internacionais } \\
\text { com eficácia no ordenamento interno e, na } \\
\text { sua ausência, estritamente de acordo com } \\
\text { os termos desta Lei'. }\end{array}$ \\
\hline & & & $\begin{array}{l}\text { Tendo em vista o dispositivo no artigo } 35 \text { do } \\
\text { próprio Projeto de Lei, que prevê a } \\
\text { homologação da sentença arbitral } \\
\text { estrangeira, pelo Supremo Tribunal Federal } \\
\text { (STF), como mecanismo intrínseco à } \\
\text { soberania do Estado brasileiro, para conferir } \\
\text { execução a ato estatal ou equivalente de } \\
\text { país estrangeiro, sugerimos a supressão do } \\
\text { artigo } 34 \text { do Projeto de Lei, que possibilita às } \\
\text { partes a utilização pela arbitragem das '[...] } \\
\text { regras internacionais de comércio'”. }\end{array}$ \\
\hline & & & $\begin{array}{l}\text { "Impõe-se a análise de um primeiro que diz } \\
\text { respeito à constitucionalidade do projeto. } \\
\text { Não atingiria ela a jurisdição, de forma a } \\
\text { infringir a Constituição das República? [...] a } \\
\text { resposta é negativa [...] O instituto da } \\
\text { arbitragem é, não só uma exigência } \\
\text { moderna, como não atinge o monopólio da }\end{array}$ \\
\hline
\end{tabular}




\begin{tabular}{|c|c|c|c|}
\hline \multirow[t]{2}{*}{$\begin{array}{l}\text { Régis de } \\
\text { Oliveira }\end{array}$} & $\begin{array}{l}\text { PSDB- } \\
\text { SP }\end{array}$ & $\begin{array}{l}\text { Parecer do Deputado } \\
\text { pela } \\
\text { constitucionalidade do } \\
\text { Projeto. }\end{array}$ & $\begin{array}{l}\text { jurisdição pelo Poder Judiciário. Ao contrário, } \\
\text { é mais uma oportunidade de participação } \\
\text { leiga na prestação da justiça [...] no caso de } \\
\text { arbitragem, as relações jurídicas resolvem- } \\
\text { se pela livre vontade das partes. Enquanto } \\
\text { não há invasão ao direito que deva ser } \\
\text { solucionado pela intervenção do Estado, o } \\
\text { Estado mantém-se alheio à demanda [...] Vê- } \\
\text { se, claramente, que não há superação do } \\
\text { poder Judiciário. Ao contrário, é ele } \\
\text { chamado, convocado, sempre que houver } \\
\text { necessidade de invasão da esfera jurídica } \\
\text { íntima de uma das partes da cláusula } \\
\text { compromissória. [...] Não há, como se } \\
\text { percebe, qualquer inconstitucionalidade no } \\
\text { projeto, em relação à quebra da cláusula } \\
\text { pétrea [...] Caso incorra qualquer dúvida } \\
\text { sobre o direito e as partes aceitem a solução } \\
\text { sem qualquer controvérsia, saneia-se o } \\
\text { problema como qualquer outra decisão } \\
\text { dadas entre as partes. Se estes concordam } \\
\text { na solução, opera-se a pacificação da lide ao } \\
\text { lado do Judiciário. Nem se pode dizer que a } 11 \\
\text { decidibilidade social seja menor importância } \\
\text { que a judicial. As lides são compostas } \\
\text { amigavelmente, o que acelera o processo } \\
\text { decisório e de pacificação. Apenas no } \\
\text { confronto é que se busca o Judiciário. É o } \\
\text { caso do projeto em tela. Tal como as lides } \\
\text { são pacificadas socialmente, da mesma } \\
\text { forma busca-se o árbitro informal para } \\
\text { solução das pendências. Enquanto a solução } \\
\text { é buscada e encontrada informalmente, o } \\
\text { Judiciário mantém-se ao lado dela, mas } \\
\text { permanece como poder, sobranceiro e à } \\
\text { disposição das partes, para a solução da } \\
\text { querela, quando do conflito e quanto dele } \\
\text { decorrer lesão ou ameaça de lesão". } \\
\end{array}$ \\
\hline & & & $\begin{array}{l}\text { "Enquanto na Europa, Ásia, África e América } \\
\text { do Sul buscam as diversas nações } \\
\text { mecanismos ágeis, rápidos e eficazes de } \\
\text { soluça de controvérsias, as emendas } \\
\text { propostas pelo nobre Deputado tendem a } \\
\text { cristalizar técnicas superadas, repropondo } \\
\text { questões que a doutrina há muito já resolveu } \\
\text { (como, por exemplo, a suposta } \\
\text { inconstitucionalidade do art. } 18, \text { bem como a }\end{array}$ \\
\hline
\end{tabular}




\begin{tabular}{|c|c|c|c|}
\hline $\begin{array}{l}\text { Celso } \\
\text { Russomano }\end{array}$ & $\begin{array}{l}\text { PSDB- } \\
\text { SP }\end{array}$ & $\begin{array}{l}\text { Relatório pela rejeição } \\
\text { de todas as emendas } \\
\text { propostas pelos } \\
\text { Deputados do PT e } \\
\text { PCdoB. }\end{array}$ & $\begin{array}{l}\text { nomenclatura moderna e cientificamente } \\
\text { adequada adotada no projeto), com apego } \\
\text { inconcebível a garantias meramente formais } \\
\text { de justiça; enquanto nos países civilizados } \\
\text { procura-se mecanismo de solução de } \\
\text { controvérsias independente do Poder } \\
\text { Judiciário, as emendas propostas caminham } \\
\text { em sentido contrário, apregoando a } \\
\text { necessidade de maior intervenção do } \\
\text { Estado; enquanto procura-se no mundo } \\
\text { inteiro ampliar o âmbito de aplicação dos } \\
\text { meios alternativos de solução e } \\
\text { controvérsias, as emendas propostas } \\
\text { tendem a limitar a utilização do juízo arbitral" }\end{array}$ \\
\hline
\end{tabular}

FONTE: Diários do Congresso Nacional (BRASIL. CÂMARA DOS DEPUTADOS, 2011).

O núcleo do debate opõe a busca da legitimidade para as decisões arbitrais que seriam proferidas por árbitros privados ao monopólio da jurisdição detido pelos magistrados vinculados ao poder judicial estatal. Também é mobilizado, como aspecto "favorável", o argumento da "agilidade" da arbitragem e sua ampla difusão em "países civilizados". Interessa notar que o debate legislativo reproduz o debate acadêmico disciplinar sobre a arbitragem. À aprovação de uma lei específica para regular essa prática corresponde a busca pela construção de uma "doutrina" que reproduz a idéia da "eficiência" das decisões arbitrais assim como as tentativas de reconhecimento da prática arbitral no espaço jurídico, tanto "prático" quanto disciplinar.

IV. AUTORES E PUBLICAÇÕES SOBRE ARBITRAGEM: ALEGITIMAÇÃO DE UMA NOVA EXPERTISE

A proliferação de publicações tendo por tema a arbitragem ao longo das décadas de 1990 e 2000 é bastante indicativa do investimento na construção de uma especialidade intelectual e disciplinar. Tanto a edição de livros quanto a institucionalização de revistas especializadas contribuem para "fazer existir" um espaço de justiça arbitral, assim como evidenciam sua penetração no espaço do ensino universitário, difundindo uma abordagem do Direito ancorada em conceitos derivados da ciência econômica.

As publicações abrangem "comentários" à lei de arbitragem e sua relação com o sistema jurídico, monografias sobre a técnica e as práticas de negociação, a relação das práticas com o sistema judicial estatal e noções mais abstratas que relacionam a discussão sobre arbitragem no quadro da construção de teorias que "aproximam" o Direito e a Economia. Também há uma preocupação em analisar a recepção das práticas arbitrais no âmbito do poder Judiciário por meio da publicação de decisões judiciais comentadas por especialistas. São representativas dessa difusão as cinco revistas de circulação nacional especializadas no tema, em sua grande maioria, fundadas ao longo da década de 2000. 
TABELA3 - PERIÓDICOS NACIONAIS DE ARBITRAGEM

\begin{tabular}{|c|c|c|c|c|}
\hline & Nome do periódico & Início & $\begin{array}{l}\mathrm{N}^{\circ} \text { de } \\
\text { edições }\end{array}$ & Tema-Conteúdo predominante \\
\hline 1 & $\begin{array}{l}\text { Revista Brasileira de Arbitragem. } \\
\text { Editada pelo Comitê Brasileiro de } \\
\text { Arbitragem (CBAR). } \\
\text { Periodicidade: Trimestral. }\end{array}$ & 2003 & 26 & $\begin{array}{l}\text { - Resenhas de livros } \\
\text { - Acórdãos judiciais } \\
\text { - Regulamentos e notícias sobre } \\
\text { arbitragens } \\
\text { - Comentários a laudos arbitrais }\end{array}$ \\
\hline 2 & $\begin{array}{l}\text { Revista de Arbitragem e Mediação. } \\
\text { Editora Revista dos Tribunais. Editada por } \\
\text { Arnold Wald, Presidente da Academia } \\
\text { Internacional de Direito e Economia. } \\
\text { Periodicidade: trimestral. }\end{array}$ & 2003 & 24 & $\begin{array}{l}\text { - Doutrina jurídica Nacional e } \\
\text { Internacional } \\
\text { - Legislação e Notas } \\
\text { - Resenhas }\end{array}$ \\
\hline 3 & $\begin{array}{l}\text { Revista do Direito Bancário, do Mercado } \\
\text { de Capitais e da Arbitragem Organizador: } \\
\text { Arnold Wald. Periodicidade: trimestral. }\end{array}$ & 1998 & 54 & $\begin{array}{l}\text { - Acórdãos judiciais comentados } \\
\text { - Decisões Administrativas } \\
\text { (regulamentação econômica) } \\
\text { - Direito Comparado } \\
\text { - Direito Bancário } \\
\text { - Projetos Legislativos }\end{array}$ \\
\hline 4 & $\begin{array}{l}\text { Revista de Mediação e Arbitragem } \\
\text { Empresarial. } \\
\text { Editada pela Câmara Brasileira de } \\
\text { Mediação e Arbitragem Empresarial } \\
\text { (Cbmae). } \\
\text { Periodicidade: mensal. }\end{array}$ & 2004 & 33 & - Informativa \\
\hline 5 & $\begin{array}{l}\text { Estudos em } \\
\text { Arbitragem, Mediação } \\
\text { e Negociação. } \\
\text { Direção: André Gomma de Azevedo. } \\
\text { Periodicidade: anual. }\end{array}$ & 2002 & 8 & $\begin{array}{l}\text { - Artigos acadêmicos sobre } \\
\text { arbitragem } \\
\text { - Acórdãos de decisões judiciais } \\
\text { - Resenhas }\end{array}$ \\
\hline
\end{tabular}

FONTE: Engelmann (2010).

No mesmo sentido das publicações periódicas também proliferam as edições de livros sobre arbitragem. Para a construção de uma amostra das publicações correntes no tema, realizou-se buscas em sites de livrarias ${ }^{8}$ pela expressão "arbitragem". Foram encontrados 163 títulos sobre o tema, sendo que 150 tratam especificamente sobre arbitragem comercial. Destes, foram selecionados 50 livros e autores cujos trabalhos

\footnotetext{
8 Iniciou-se a busca por sites de diversas livrarias que comercializam livros de direito. O site que apresentou maior concentração de publicações sobre arbitragem foi o da Livraria Cultura, motivo pelo qual foi usado como referencial. Foram excluídas as publicações de autores estrangeiros. $\mathrm{O} N$ construído nessas bases obviamente não é definitivo, mas permite uma amostra com indicações relevantes para o quadro da pesquisa apresentada.
}

enfocam a doutrina da arbitragem, visto que uma grande parte é composta de comentários e resumos sobre a lei de arbitragem aprovada em 1996. Visando à construção de um mapa do perfil de inserção profissional e acadêmico dos autores, foram coletadas informações biográficas que permitiram, por meio da comparação de seus percursos, indicações sobre seu posicionamento no espaço jurídico e econômico.

Também a partir da análise dos dados construídos, buscou-se uma melhor exploração dos espaços de formação acadêmica e exercício profissional que circundam o universo da arbitragem. A formação universitária de graduação predominante entre os autores é a formação jurídica, sendo que a maioria possui cursos de pós-graduação curtos - especializações em Direito 
empresarial - ou mestrados e doutorados em Direito. Também constatou-se que, majoritariamente, os autores aparecem como associados a câmaras nacionais e internacionais de arbitragem.
Os locais de formação de graduação são bastante diversificados, assim como os de pósgraduação. Estes são importantes para a análise da construção dos principais pólos de onde irradiam as doutrinas, visto que muitas publicações originam-se de trabalhos finais de pós-graduação.

TABELA 4 - INSTITUIÇÕES DE PÓS-GRADUAÇÃO DOS AUTORES

\begin{tabular}{|l|c|c|c|}
\hline INSTITUIÇÃo & $\begin{array}{c}\text { ESTADO- } \\
\text { PAÍS }\end{array}$ & FREQUÊNCIA & $\%$ \\
\hline USP (Programa de Pós-Graduação em Direito) & SP & 7 & 16,6 \\
PUCSP (PPG Direito) & SP & 7 & 16,6 \\
UERJ (PPG Direito) & RJ & 2 & 4,76 \\
PUC-PR (PPG Direito Econômico) & PR & 2 & 4,76 \\
UFSC (PPG Direito) & SC & 2 & 4,76 \\
Université Paris II, Institute du Droit Privé (DEA) & FRANÇA & 2 & 4,76 \\
The University of Chicago (Master Law) & EUA & 2 & 4,76 \\
FGV (Especialização em Direito e Economia) & SP & 1 & 2,38 \\
Centro Universitário Mackenzie (Especialização Direito Tributário) & SP & 1 & 2,38 \\
Unesp (Mestrado em Direito) & SP & 1 & 2,38 \\
Universidade Estácio de Sá (Especialização em Direito Civil) & SP & 1 & 2,38 \\
Instituto Brasileiro de Estudos Tributários (Especialização em Direito & SP & 1 & 2,38 \\
Tributário) & & & \\
Ufrgs (PPG Direito) & RS & 1 & 2,38 \\
Unisinos (PPG Direito) & RS & 1 & 2,38 \\
UFMG (PPG Direito) & MG & 1 & 2,38 \\
PUC-MG (Especialização em Engenhara de avaliaçöes e perícias) & MG & 1 & 2,38 \\
UFBA (PPG em Direito Econômico) & BA & 1 & 2,38 \\
Universidad de Navarra (Postgrado Derecho) & ESPANHA & 1 & 2,38 \\
Universidade San Pablo (Postgrado Derecho) & ESPANHA & 1 & 2,38 \\
Columbia University (Master of Law) & EUA & 1 & 2,38 \\
Inst. Internacionale d'Adminsitration Publique (DEA) & FRANÇA & 1 & 2,38 \\
\hline
\end{tabular}

FONTE: Engelmann (2010).

A concentração de cursos de pós-graduação realizados em São Paulo segue a mesma tendência de localização das maiores câmaras de arbitragem também situadas nesse estado. Os dados indicam que não ocorre concentração de cursos em um pólo específico, apesar dos investimentos ao longo da década de 2000 de instituições como a Fundação Getúlio Vargas no sentido de afirmar-se como escola de formação em Direito Empresarial (ENGELMANN, 2011). Os temas dos cursos realizados também evidenciam a não sedimentação da temática "arbitragem", visto que os cursos distribuem-se em disciplinas tradicionais do Direito, como Direito Civil, Direito Tributário e Direito Empresarial.

Outro fator relevante é o baixo número de cursos de pós-graduação realizados no exterior. A ocupação predominante dos autores é a advocacia. A maioria combina a condição de advogado com o magistério superior evidenciando que a produção de uma "doutrina da arbitragem" contempla um 
significativo investimento em um "novo saber disciplinar" presente no ensino do Direito e indispensável para a tentativa de legitimar uma categoria de práticos da justiça arbitral. Como demonstra Dezalay (1989; 1993), a emergência de novas doutrinas jurídicas não é uma mera batalha entre perspectivas "científicas" sobre o Direito, mas repercute mais amplamente lutas políticas e profissionais e a produção de grupos que disputam o sentido da jurisdição.

\section{TABELA 5 - OCUPAÇÕES DOS AUTORES}

\begin{tabular}{|lcc|}
\hline OCUPAÇÃO & FREQUÊNCIA & $\%$ \\
\hline Advogado e professor & 21 & 47,7 \\
Advogado & 8 & 18,18 \\
Professor & 8 & 18,18 \\
Magistrado e professor & 4 & 9,09 \\
Jornalista & 2 & 4,54 \\
Perito Oficial (engenheiro e advogado) & 1 & 2,27 \\
\hline
\end{tabular}

FONTE: Engelmann (2010).

Analisando os trajetos profissionais também se percebe que a maioria dos que são apenas advogados declaram no currículo ser sócios de escritórios, vinculando-se a um padrão dos business lawyers em que o exercício da advocacia empresarial exclui o exercício do magistério, assim como o investimento em cursos de pós-graduação mais extensos. Para o caso dos que exercem apenas a atividade professor predominam mulheres com titulação recente de Doutorado, o que também pode ser relacionado à tendência de maior institucionalização dos programas de pósgraduação em Direito com docentes titulados e com dedicação exclusiva ao ensino universitário (ver ENGELMANN, 2008)

Importa notar, desse segmento de autores, a combinação entre expertise e a construção de um capital de notoriedade no âmbito da arbitragem. Ou seja, embora a adesão a uma "comunidade epistêmica", como definem Dezalay e Garth (1996) ao tratarem da difusão das idéias da arbitragem, seja fundamental para a expansão desse perfil de práticas, ela não se dissocia e nem subsiste sem a gestão permanente de um capital de notoriedade.

Esse capital é gerido e obtido na adesão dos autores e práticos a diversas modalidades de associações, passagem pela direção de câmaras e inserção na advocacia empresarial. Como se verá no caso específico do Rio Grande do Sul, esse imbricamento entre um capital de notoriedade no meio empresarial e o investimento na construção da expertise caminham sempre juntos, e também contribuem para a hierarquização, posicionando no topo aqueles que obtêm êxito em combinar altos graus de conhecimentos técnicos e inserção no meio empresarial.

\section{O ESPAÇO DOS ÁRBITROS: O CASO REPRESENTATIVO DO RIO GRANDE DO SUL}

Em uma primeira exploração dos perfis das câmaras de arbitragem foram encontradas diversas modalidades que conformam um espaço de atuação principalmente de advogados empresariais, mas também de outros grupos profissionais, como contabilistas, engenheiros e administradores, que figuram como árbitros de contenciosos envolvendo grandes empresas comerciais e industriais. Há pouca regulamentação no concernente à estruturação dessas câmaras que funcionam como uma espécie de justiça privada e que contém, em seus documentos de fundação, tomadas de posição que remetem a uma crítica à "ineficiência" e "lentidão" do sistema judicial estatal na solução de litígios. Os documentos das câmaras, assim como o discurso mobilizado pelos árbitros, indicam uma disputa simbólica em torno da jurisdição de conflitos.

Entretanto, diferentemente dos juízes, profissionais da jurisdição vinculados ao sistema estatal e portadores de um capital jurídico 
certificado pelo Estado, os árbitros não se apresentam como uma categoria que reivindica uma posição no espaço do poder de Estado. O exercício da arbitragem é apresentado como uma espécie de cargo honorífico e temporário exercido por qualquer indivíduo que tenha notoriedade ou perícia e reconhecimento das partes em conflito. Nesse sentido, trata-se de uma "condição", vinculada a uma atuação temporária em um contencioso determinado, onde a "confiança", ou seja, o crédito das partes, é fundamental.

As câmaras de arbitragem possuem diferentes modalidades de organização. A partir de uma análise dos perfis dessas organizações em escala nacional chegou-se a três grandes tipos: $(i)$ câmaras independentes, nacionais, estaduais ou municipais, constituídas privadamente ou por meio de convênios com secretarias de justiça e prefeituras, e em alguns casos denominadas de tribunais arbitrais; (ii) câmaras vinculadas a setores econômicos específicos, como o setor de seguros, instituições do mercado financeiro ou associações profissionais; (iii) as câmaras vinculadas ao setor empresarial criadas no âmbito de associações e federações empresariais - de amplitude federal ou estadual - ou câmara de comércio exterior, envolvendo acordos de cooperação com outros países.

No caso do Rio Grande do Sul, a principal câmara é vinculada à Federação das Associações Comerciais e de Serviços (Federasul) localizada em Porto Alegre. Entretanto, o levantamento do conjunto mostrou a existência de outros perfis de arbitragem localizados em municípios do interior do Estado incluindo organismos que propõem serviços voltados a um público não empresarial. A maioria das câmaras existentes, entretanto, é filiada às instituições nacionais que certificam a prática da arbitragem junto ao meio empresarial: a Confederação das Associações Comerciais e Empresariais do Brasil (CACB) e o Conselho Nacional das Instituições de Mediação e Arbitragem (Conima), sediados em São Paulo. Da mesma forma, participam de convênios com o Banco Inter-Americano de Desenvolvimento (BID) reproduzindo modelos de organização internacionais.

Algumas câmaras fundadas no interior do Estado foram desativadas em um período que varia de um a três anos após a fundação. Nesses casos, os contatos e entrevistas realizados com dirigentes indicaram que se tratava de iniciativas articuladas por escritórios de advocacia ou até advogados individuais. O mesmo ocorre em casos de câmaras que propõem o uso da Lei da Arbitragem para a mediação de conflitos "comunitários", atuando em escala local, em pequenos conflitos, como o "Tribunal de Mediação e Arbitragem do RS". Embora não seja o objeto principal do trabalho, é importante apontar o fenômeno da existência de organismos que propagam o uso do instituto legal da arbitragem para a promoção de uma espécie de "justiça comunitária" de natureza privada.

TABELA 6 - CÂMARAS DE MEDIAÇÃO E ARBITRAGEM NO RIO GRANDE DO SUL

\begin{tabular}{|c|c|c|}
\hline NOME & FUNDAÇÃO & $\begin{array}{c}\text { VíNCULO } \\
\text { (SETOR ECONÔMICO, } \\
\text { ASSOCIAÇÃO ETC.) }\end{array}$ \\
\hline $\begin{array}{l}\text { Instituto Nacional de Mediação e Arbitragem do Rio } \\
\text { Grande do Sul (Inama-RS) }\end{array}$ & 1991 & CONIMA \\
\hline $\begin{array}{l}\text { Câmara de Mediação e Juizado Arbitral de Marau } \\
\text { (Camejam) }\end{array}$ & $\begin{array}{c}1999 \\
\text { (desativada) }\end{array}$ & CACB \\
\hline $\begin{array}{l}\text { Tribunal de Mediação e Juizado Arbitral da Região } \\
\text { Centro do Rio Grande do Sul (TMJA-RCRS) }\end{array}$ & 1999 & CACB \\
\hline $\begin{array}{l}\text { Organização de Mediação e Arbitragem S/C Ltda. } \\
\text { (Mediar) }\end{array}$ & 2000 & $\begin{array}{c}\text { CACB } \\
\text { (com financiamento do BID) }\end{array}$ \\
\hline Centro de Mediação e Arbitragem (RS) & 2000 & CACB \\
\hline $\begin{array}{l}\text { Câmara de Mediação e Arbitragem de Caxias do Sul } \\
\text { (Camacs-RS) }\end{array}$ & 2001 & Conima \\
\hline Tribunal Arbitral de Santo Ângelo e Missões (Tasam) & $\begin{array}{c}2001 \\
\text { (desativado) }\end{array}$ & CACB \\
\hline $\begin{array}{l}\text { Tribunal de Mediação, Conciliação e Juízo Arbitral } \\
\text { de Panambi (RS) }\end{array}$ & $\begin{array}{c}2003 \\
\text { (desativado) }\end{array}$ & CACB \\
\hline
\end{tabular}




\begin{tabular}{|lcc|}
\hline $\begin{array}{l}\text { Câmara de Mediação e Arbitragem do Conselho } \\
\text { Regional de Administração do Rio Grande do Sul } \\
\text { (CMA-CRA-RS) }\end{array}$ & 2004 & Conima \\
Câmara de Mediação e Arbitragem da Federasul & 2006 & CACB \\
Tribunal de Mediação e Arbitragem do RS & 2000 & $\begin{array}{c}\text { (com financiamento do BID) } \\
\text { nenhum }\end{array}$
\end{tabular}

FONTES: Conima (2011); CACB (2011); Engelmann (2010).

Para a seleção de uma amostra da população de árbitros tendo em vista a construção de dados sobre as biografias comparadas, tomou-se como referência o quadro de árbitros da Federasul $(\mathrm{N}=$ 24), cujo modelo de organização está mais próximo dos propostos padrões internacionais voltados para o meio empresarial. Em segundo lugar, foi utilizado o anuário Análise advocacia 500 (ANÁLISE EDITORIAL, 2007), que contém informações sobre as maiores sociedades de advogados do país, utilizando como critério o mapeamento dos escritórios com sede no Rio Grande do Sul, cujos sócios apresentavam vínculos com a prática da arbitragem, chegando-se ao $\mathrm{N}$ de 14 . A partir dessas duas primeiras fontes, e da exploração de dados de trajetos profissionais e acadêmicos dos currículos vitae, foram agrupados três grandes perfis de árbitros.

Um primeiro agrupamento é composto de "juristas notáveis", que tem destaque no espaço jurídico do Rio Grande do Sul, abrangendo bacharéis que ocuparam cargos de direção no Tribunal de Justiça do Estado ou foram ministros em tribunais superiores ou ainda advogados formados nas décadas de 1950 e 1960 com produção intelectual e destaque na elite jurídica. Uma segunda composição compreende "advogados de negócios", vinculados aos escritórios de advocacia empresarial do Estado, que atuam também na arbitragem e, invariavelmente, são mais jovens do que os juristas com passagem pelo poder Judiciário. Finalmente, um terceiro segmento contempla os "peritos", sendo constituído por indivíduos não formados em Direito, em grande maioria engenheiros, arquitetos, contabilistas, economistas e administradores.

A comparação dos trajetos e inserção profissionais, acadêmicos, associativos e políticos dos três grupos permitiu indicações relevantes sobre os recursos possuídos e mobilizados para a construção da posição de árbitro.

TABELA 7 - PERFIL DOS ÁRBITROS NO RIO GRANDE DO SUL

\begin{tabular}{|c|c|c|c|c|c|c|c|c|}
\hline $\begin{array}{l}\text { MODALI- } \\
\text { DADE }\end{array}$ & \begin{tabular}{|c} 
PARTICIPA- \\
ÇÃO EM \\
ASSOCIA- \\
ÇÃO \\
COMERCIAL \\
OU \\
INDUSTRIAL
\end{tabular} & \begin{tabular}{|} 
PARTICIPA- \\
ÇÃONA \\
DIREÇÃODE \\
INSTITUTOS \\
DEADVO- \\
GADOSE/OU \\
OAB
\end{tabular} & $\begin{array}{c}\text { OCUPA- } \\
\text { ÇÃODE } \\
\text { POSTOS } \\
\text { NO } \\
\text { SETOR } \\
\text { PRIVADO }\end{array}$ & \begin{tabular}{|} 
OCUPAÇÃO \\
DE POS- \\
TOS NO \\
PODER \\
JUDICIÁRIO
\end{tabular} & $\begin{array}{c}\text { PRODU- } \\
\text { ÇÃO INTE- } \\
\text { LECTUAL } \\
\text { (TEMA } \\
\text { ARBITRA- } \\
\text { GEM) }\end{array}$ & $\begin{array}{c}\text { PRODU- } \\
\text { ÇÃO } \\
\text { INTELEC- } \\
\text { TUAL } \\
\text { GERAL }\end{array}$ & \begin{tabular}{|c} 
MAGIS- \\
TÉRIO \\
SUPE- \\
RIOR
\end{tabular} & $\begin{array}{l}\text { INSER- } \\
\text { ÇÃO } \\
\text { INTER- } \\
\text { NACIO } \\
\text { NAL }\end{array}$ \\
\hline $\begin{array}{l}\text { Juristas } \\
(N=5)\end{array}$ & Não & Sim & Não & Sim & Não & Sim & Sim & Não \\
\hline $\begin{array}{l}\text { Advoga- } \\
\text { dos de } \\
\text { negócios } \\
(N=10)\end{array}$ & Sim & Não & Não & Não & Sim & Não & Sim & Não \\
\hline $\begin{array}{l}\text { Peritos } \\
(N=10)\end{array}$ & Sim & Não & Sim & Não & Não & Não & Sim & Não \\
\hline
\end{tabular}

FONTE: Engelmann (2010). 
O primeiro agrupamento caracterizado por bacharéis em Direito que ocuparam postos na cúpula do poder Judiciário ou obtiveram destaque no espaço da advocacia caracteriza-se principalmente por seu ingresso tardio - após a aposentadoria como Desembargador ou Ministro de Tribunal Superior - na condição de Árbitro. Também é um conjunto de indivíduos minoritário em relação aos advogados de negócios e aos peritos.

A notoriedade obtida no meio jurídico soma e confunde-se com a origem social no meio de grandes famílias de juristas ou políticos e ostentação de um grande capital cultural. Destacase a ocupação de postos de direção no Tribunal de Justiça, passagem por conselhos - tais como o conselho penitenciário -, diretorias e conselhos consultivos da Ordem dos Advogados do Brasil (OAB) e na direção do Instituto dos Advogados do Rio Grande do Sul. O exercício dessas funções e cargos honoríficos combina-se com a gestão de um capital social que envolve o pertencimento a diversas espécies de associações e institutos fora do espaço jurídico. Uma notoriedade como "intelectual" derivada da dedicação às "atividades culturais" e "literárias", ostentação de medalhas e comendas conferidas por instituições públicas e por institutos culturais que certificam "destaque social".

Em um mesmo sentido, a carreira paralela no magistério superior, assim como as publicações de livros sobre temas jurídicos, soma-se à construção da posição de "notável saber jurídico". Observa-se, nesse caso, que a maioria produz na área de Direito Processual - disciplina típica do "Direito de Estado" e não ostenta a produção de publicações na área de Direito Empresarial ou da Arbitragem. Da mesma forma, esse grupo não participa de associações comerciais e industriais, indicando que sua notoriedade, garantida pela posição de árbitro, é reconvertida de fora do espaço empresarial.

No caso dos "advogados de negócios", a notoriedade deriva predominantemente da inserção no mundo empresarial por meio da ocupação de postos de assessoria jurídica em associações comerciais e industriais, a presença em diretorias e conselhos da $\mathrm{OAB}$, além do domínio de uma expertise relacionada ao Direito Privado, que pode ser detectada no número de agentes desse pólo que lecionam e possuem produção intelectual na área do Direito Empresarial. Além da produção intelectual destaca-se, em alguns casos, o investimento na propagação das idéias relacionadas à arbitragem e, mais amplamente, aos movimentos de reformulação das teorias do Direito pela ciência econômica, como o law \& economics. Pode-se incluir nesse aspecto a fundação, por um grupo de advogados de empresas, em 2006, do Instituto de Direito e Economia do Rio Grande do Sul.

A principal diferença desse pólo de advogados em relação aos bacharéis com maior notoriedade no mundo jurídico é sua presença junto a associações empresariais e a ausência de passagem pela alta burocracia judiciária. Também se pode destacar que se trata de um agrupamento graduado majoritariamente na década de 1990 , o que contrasta com o primeiro pólo de juristas formado nas décadas de 1950 e 1960.

A terceira categoria de árbitros tem como principal recurso para a construção de sua condição a posse e mobilização da perícia técnica. É um grupo que se distingue dos outros dois por não ser constituído por bacharéis em Direito. Formado por engenheiros, arquitetos, administradores e contabilistas, a maioria possui o título de "perito judicial" que se trata de uma certificação que permite a emissão de laudos periciais (tais como auditorias, laudos técnicos de engenharia, veracidade de documentos etc.) que intervém em processos judiciais. A condição de "peritos" é talvez a face mais visível da mobilização de uma condição de expert como recurso para a proferição de decisões em conflitos empresariais, embora por si só não seja condição suficiente para adquirir notoriedade para a função de árbitro.

A combinação da condição de perito com a inserção em associações empresariais e, em muitos casos, a ocupação de postos de gerência e direção em empresas privadas, é um componente fundamental para a construção da notoriedade dos peritos e seu credenciamento para participarem do mundo da arbitragem. Também se destaca, nesse pólo, o magistério superior, relacionado a temas técnicos, o que adiciona uma certificação acadêmica à condição de especialista.

Finalmente é importante ressaltar que em nenhum dos três pólos analisados aparece como relevante a inserção internacional medida pela freqüência de cursos de pós-graduação no exterior, pertencimento a redes internacionais acadêmicas ou relacionadas a associações de árbitros. Esse 
fator não se deve apenas à condição mais periférica do Rio Grande do Sul no espaço econômico nacional, visto que entre os autores de livros sobre arbitragem posicionados em diversas regiões, também a inserção internacional é frágil. Talvez essa pouca participação em fóruns internacionais seja mais um dos indicativos da incipiência da penetração da arbitragem no âmbito dos negócios no mundo empresarial brasileiro que se soma à resistência desse modelo de justiça por parte das elites judiciais posicionadas no sistema estatal.

As entrevistas informativas realizadas com árbitros presentes nas listas da Federasul e outras câmaras no Rio Grande do Sul evidenciam a natureza precária da atuação dos árbitros. Embora tenha havido convênios com o BID e recrutamento e treinamento de indivíduos para essas práticas, os casos de atuação efetiva são escassos restringindo-se a demandas pontuais de advogados vinculados a grandes escritórios de advocacia especializados no direito empresarial.

\section{CONCLUSÕES}

Os dados produzidos na pesquisa sobre os trajetos comparados dos autores sobre arbitragem e dos árbitros analisados no Rio Grande do Sul, assim como do processo de mobilização em torno da aprovação da Lei da Arbitragem, mostram um movimento pela construção de um modelo de justiça profundamente imbricado ao espaço empresarial e dos negócios; o que envolve desde a ideologia liberal dos institutos empresarias e o perfil de lideranças políticas que apóia a construção da lei até as teorias econômicas mobilizadas para fundamentar simbolicamente esse espaço.
Da mesma forma, as espécies de recursos mobilizados pelos árbitros na construção da sua notoriedade se posicionam ao lado do capital jurídico mais clássico. Se a notoriedade como grande jurista é construída a partir do acúmulo de um capital jurídico certificado pela passagem em postos na cúpula do poder Judiciário e com a participação em associações de juristas e sucesso em uma longa carreira como advogado, a construção da notoriedade necessária para ser um "árbitro" advém principalmente de outro caminho. Trata-se de um eixo que combina expertises com um capital de relações sociais junto ao meio empresarial, o qual pode ser medido principalmente pela presença em diretorias de associações comerciais e industriais.

Embora a presença de árbitros "grandes juristas" que passaram pela cúpula de tribunais, o perfil mais recorrente ostenta uma forte inserção em associações empresariais, institutos, câmaras de comércio e na advocacia empresarial. Trata-se do pólo que concorre, inclusive, com uma espécie de árbitro "não jurista" que ancora sua notoriedade na condição de "perito" combinada com a notoriedade junto ao meio empresarial.

A oposição entre os trajetos que contribuem para a notoriedade dos árbitros aos que condicionam a notoriedade dos juristas talvez ajude a explicar as dificuldades de consolidação da prática da arbitragem no contexto brasileiro. Mesmo com a existência de marcos legais, da proliferação de câmaras e da transferência de modelos de organização padronizados internacionalmente, o monopólio da jurisdição permanece com aqueles que detêm o capital jurídico que, por definição, é fortemente certificado pelo Estado.

Fabiano Engelmann (fabengel@gmail.com) é Doutor em Ciência Política pela Universidade Federal do Rio Grande do Sul (Ufrgs) e Professor de Ciência Política na mesma universidade.

\section{REFERÊNCIAS BIBLIOGRÁFICAS}

ADORNO, S. 1988. Os aprendizes do poder. Rio de Janeiro: Paz e Terra.

AGRIKOLIANSKY, E. \& SOMMIER, I. 2005. Radiographie du mouvement altermondialiste. Paris: La Dispute.

CARVAlHO, J. M. C. 1996. A construção da ordem: a elite política imperial. $2^{\mathrm{a}}$ ed. Rio de Janeiro: UFRJ.
COMMAILLE, J. 2007. La justice entre détraditionnalisation, néolibératisation et démocratisation: vers une théorie de Sociologie Politique. In: COMMAILlE, J. \& KALUSZYNSKI, M. (eds.). La Fonction politique de la justice. Paris: La Découverte.

DEZALAY, Y. 1989. Marchands de Droit: la restructuturation de l'ordre juridique 
international par les multinationales du droit. Paris: Fayard

1993. La Production doctrinale comme objet et terrain de luttes politiques et professionnelles. In: POIRMEUR, Y. \& BERNARD, A. (eds.). La Doctrine juridique. Paris: PUF.

DEZALAY, Y. \& GARTH, B. 1996. Dealing in Virtue: International Commercial Arbitration and the Construction of a Transnational Legal Order. Chicago: University of Chicago.

2002. The Internationalization of Palace Wars: Lawyers, Economists, and the Contest to Transform Latin American State. Chicago: University of Chicago.

2010. Asian Legal Revivals: Lawyers in the Shadow of Empire. Chicago: University of Chicago.

ENGELMANN, F. 2006. Sociologia do campo jurídico: juristas e usos do Direito. Porto Alegre: SAFE.

2008. Estudos no exterior e mediação de modelos institucionais: o caso dos juristas brasileiros. Revista de Sociologia e Política, Curitiba, v. 16, número suplementar, p. 145157, ago. Disponível em: http://www.scielo.br/ pdf/rsocp/v16s0/a11v16s0.pdf. Acesso em: 3.mar.2013.

2010. Banco de dados do projeto "Globalização e Rule of Law: as disputas em torno do sentido político do sistema judicial brasileiro nas décadas de 90 e 2000". Projeto de pesquisa. Conselho Nacional de Desenvolvimento Científico e Tecnológico.
2011. Los abogados de negocios y la Rule of Law en el Brasil en las de cadas del $90 \mathrm{y}$ 2000. Política, Santiago, v. 49, n. 1, p. 21-41, Oct. Disponível em: http://www.revistapolitica. uchile.cl/index.php/RP/article/download/ 16274/16856. Acesso em: 3.mar.2013.

HAAS, P. 1992. Introduction: epistemic communities and international policy coordination. International Organization, Cambridge (UK), v. 46, n. 1, p 1-35, Winter.

LIMA, C. V. 1997. Cultura da arbitragem. São Paulo: Câmara Metropolitana de Mediação e Arbitragem do Estado de São Paulo. Disponível em: http://www.arbitragemsantos. com.br/ conteudo/artigos019.htm. Acesso em: 3.mar.2013.

MACHADO, R. B. 2007. A arbitragem como opção de saída para a resolução de conflitos empresariais. Porto Alegre. Dissertação (Mestrado em Ciências Sociais). Pontifícia Universidade Católica do Rio Grande do Sul.

MUNIZ, P. 2006. Operação Arbiter: a história da Lei n. 9 307/96 sobre a arbitragem comercial no Brasil. Brasília: ITN.

ROBERT, C. \& VAUCHEZ, A. 2010. L'Academie européenne: savoirs, experts et savants dans le gouvernement de l'Europe. Politix, Paris, n. 89 , p. $28-41$, Printemps.

TRUBEK, D. 2006. The "Rule of Law" in Development Assistance: Past, Present and Future. In: TRUBEK, D. M. \& SANTOS, A. (eds.). The New Law and Economic Development: A Critical Appraisal. New York: Cambridge University.

\section{OUTRAS FONTES}

ANÁlise EDITORIAL. 2007. Análise advogacia 500. São Paulo: Análise.

BRASIL. CÂMARA DOS DEPUTADOS. 2011. Diários do Congresso Nacional. Brasília: Câmara dos Deputados. Disponível em: http:/ /imagem.camara.gov.br/diarios.asp. Acesso em: 3.mar.2013.
CACB. 2011. Sítio da Confederação das Associações Comerciais e Empresariais do Brasil. Disponível em: http:// www.cacb.org.br/noticia_noticias/ver/ 2719\#.UU4ZelfyB8E. Acesso em: 3.mar.2013.

CONIMA. 2011. Sítio do Conselho Nacional das Instituições de Mediação e Arbitragem. Disponível em: http://www.conima.org.br/. Acesso em: 3.mar.2013. 


\section{Fabiano Engelmann}

This text presents the results of socio-political research on the construction of a field of arbitration in Brazil. The first part focuses on mobilization around legal arbitration as a "political cause" involving lawyers, professor and politicians connected to business associations and liberal institutions, resulting 
most importantly in the materialization of an institutional framework for arbitrating practices, Law 9307 which was promulgated in 1996. A second dimension focuses on authors and publications on arbitration, indicating the dissemination of ideas and disciplinary specialization that unfolded over the course of the 2000s. In the third part, I look at the place that arbiters occupy in Rio Grande do Sul, researching factors that condition their development. This is qualitative research that privileges several data bases, such as legal, journalistic and academic publications, curriculi vitae and semi-structured interviews. My most significant findings lie in foregrounding the legitimation difficulties that this model of conflict mediation faces vis-à-vis the judicial system, in the case in point.

KEYWORDS: Arbitration; Justice; Brazil. 

RECONNAISSANCE

\section{Fabiano Engelmann}

Le Texte expose les résultats d'une recherche socio-politique sur la construction de l'espace de l'arbitrage au Brésil. Sa première partie privilégie la mobilisation autour de la justice arbitrale autant que « cause politique » impliquant des avocats, professeurs et politiques liés aux associations du milieu d'entreprise et des instituts libéraux, et a comme principal résultat la concrétisation d'un point de repère institutionnel pour les pratiques arbitrales, la Loi 9307 promulguée en 1996. Une deuxième dimension met l'accent sur les auteurs et publications sur l'arbitrage, indiquant la diffusion d'idées et la spécialisation disciplinaire au long des années 2000. Dans la troisième partie de l'article, on aborde l'espace des arbitres à Rio Grande do Sul, en vérifiant les conditions de son développement. La recherche est du genre qualitatif et privilégie diverses bases de données, soulignant des publications légales, journalistiques et académiques, curriculi vitae et des interviews semi-structurées. On souligne, comme principal résultat, la spécification des difficultés pour la légitimation de ce modèle de médiation de conflits devant le système judiciaire de l'État dans le cas étudié.

MOTS-CLÉS: arbitrage; justice; Brésil. 


\section{ANEXO}

\section{CRONOLOGIA DALEI DAARBITRAGEM NO BRASIL}

\begin{tabular}{|c|c|}
\hline 27.maio.1981 & $\begin{array}{l}\text { Mediante solicitação do extinto Ministério da Desburocratização, o Governo Federal } \\
\text { elaborou um anteprojeto de } 28 \text { artigos que dotava a arbitragem de mecanismos que } \\
\text { permitiram o uso da instituição. Abolia a necessidade de homologação do laudo arbitral } \\
\text { que ficava equiparado a um titulo executivo extrajudicial. O projeto deixava a desejar } \\
\text { quanto à precisão técnica. }\end{array}$ \\
\hline Dd.mm.1985 & $\begin{array}{l}\text { Lei Modelo sobre Arbitragem Comercial Internacional elaborada pela Comissão das } \\
\text { Nações Unidas para o Direito Comercial Internacional (Uncitral). }\end{array}$ \\
\hline 29-31.jul.1985 & $\begin{array}{l}\text { Congresso Internacional sobre Arbitragem Comercial na Confederação Nacional do } \\
\text { Comércio. Livro reunindo os anais do congresso serviu de guia para a Operação Arbiter. }\end{array}$ \\
\hline 27.fev.1986 & $\begin{array}{l}\text { Segundo Projeto de Lei prevendo a estipulação da arbitragem. Problemas: confundia } \\
\text { arbitragem com arbitramento; simplismo no tratamento à sentenças proferidas no } \\
\text { exterior. }\end{array}$ \\
\hline Dd.jun.1988 & $\begin{array}{l}\text { Terceiro e último projeto antes do projeto que daria origem à Lei n. } 9307 / 96 \text {. Problemas: } \\
\text { laudo arbitral sujeito a recurso de apelação que seria julgado pelo Tribunal de Justiça } \\
\text { local; obrigatoriedade do árbitro em ser Bacharel em Direito; o projeto não tratou da } \\
\text { questão da homologação do laudo nem da sentença estrangeira. }\end{array}$ \\
\hline 10.abr.1989 & $\begin{array}{l}\text { Publicação do artigo "A crise do processo e a solução de controvérsias" no Diário do } \\
\text { Comércio e Indústria, de autoria do Prof. Carlos Alberto Carmona. }\end{array}$ \\
\hline Dd.mm.1990 & $\begin{array}{l}\text { Início da Operação Arbiter: reunião capitaneada por Petrônio Muniz na Associação } \\
\text { comercial de Pernambuco. Presentes empresários, advogados e membros do Instituto } \\
\text { Liberal de Pernambuco. Determinaram que houvesse uma nova reunião em São Paulo } \\
\text { na Associação Comercial. }\end{array}$ \\
\hline 5.nov.1991 & $\begin{array}{l}\text { Reunião na associação comercial de São Paulo. Presentes: Ada Grinover, Professor } \\
\text { Magano, Selma Ferreira Lemes, Carlos Alberto Carmona, Pedro Baptista Martins. } \\
\text { Objetivo da reunião: aprovar a idéia da Operação Arbiter. Resultados: (i) constituição de } \\
\text { uma comissão redatora do anteprojeto; (ii) balizamento politico-jurídico do projeto, a fim } \\
\text { de prevenir conflitos com o judiciário; (iii) não inclusão da problemática trabalhista no } \\
\text { anteprojeto; (iv) a discussão do anteprojeto seria realizada em evento nacional na } \\
\text { cidade de Curitiba, quatro meses depois; ( } \text { v) apresentação do Projeto de Lei em reunião } \\
\text { no dia } 9 \text { de dezembro de } 1991 \text {, em reunião na Associação Comercial de São Paulo. }\end{array}$ \\
\hline 9.dez.1991 & $\begin{array}{l}\text { Reunião na Associação Comercial de São Paulo. Comissão redatora, composta por } \\
\text { Selma Ferreira Lemes, Carlos Alberto Carmona e Pedro Baptista Martins, apresenta o } \\
\text { anteprojeto. }\end{array}$ \\
\hline 17.dez.1991 & $\begin{array}{l}\text { Protocolo de Brasília sugere o uso da arbitragem para solução de litígios no âmbito do } \\
\text { Mercosul. }\end{array}$ \\
\hline \multirow[t]{2}{*}{ 27.abr.1992 } & $\begin{array}{l}\text { Seminário Nacional de Arbitragem, Curitiba-PR. Organizado pela Coordenação Nacional } \\
\text { da Operação Arbiter com o apoio do Instituto Liberal do Paraná. Reuniram-se mais de } \\
300 \text { pessoas, entre advogados, magistrados, promotores públicos, professores, } \\
\text { acadêmicos, empresários e profissionais liberais. Ao fim do evento foi aprovado por } \\
\text { aclamação o anteprojeto redigido por Carlos Carmona, Selma Lemes e Pedro Baptista } \\
\text { Marins. }\end{array}$ \\
\hline & $\begin{array}{l}\text { Entidades apoiadoras: Conselho Nacional das Associações Comerciais, Associação } \\
\text { Comercial de São Paulo, Instituto Brasileiro de Direito Processual, Centro Brasileiro de } \\
\text { Arbitragem, Comissão de Arbitragem da Câmara de Comércio Brasil-Canadá, } \\
\text { Associação de Desenvolvimento Executivo (Prodex), Câmara Internacional de Comércio }\end{array}$ \\
\hline
\end{tabular}




\begin{tabular}{|c|c|}
\hline & $\begin{array}{l}\text { do Brasil, Associação Alumini da América do Sul da Academy of America and } \\
\text { International Law da América do Sul, Federação das Indústrias de São Paulo, Centro } \\
\text { das Indústrias de São Paulo, Banco Bamerindus do Brasil S.A, Associação Brasileira de } \\
\text { Shopping Centers, Ordem dos Advogados do Brasil - Seccional Pernambuco. }\end{array}$ \\
\hline 29.abr.1992 & Senador Marco Maciel relata ao Senado o evento de Curitiba. \\
\hline 2.jun.1992 & $\begin{array}{l}\text { Anteprojeto entregue ao Senador Marco Maciel na Sala da Presidência do Senado } \\
\text { Federal em Brasilia. Assinado por: Donald Stweart Júnior, Petronio Raymundo } \\
\text { Gonçalves Muniz, Reginaldo Soares de Andrade, Antônio Mário de Abreu Pinto, Selma } \\
\text { Maria Ferreira Lemes, Carlos Albert Carmona e Pedro Baptista Martins. }\end{array}$ \\
\hline 3.jun.1992 & $\begin{array}{l}\text { Senador Marco Maciel protocolou o documento. Registrado sob PLS } 78 / 92 \text {, distribuído } \\
\text { ao Relator, Senador Antônio Mariz, do Partido do mMovimento Democrático Brasileiro } \\
\text { (PMDB) paraibano. }\end{array}$ \\
\hline 3.jun.1993 & $\begin{array}{l}\text { Comissão de Constituição, Justiça e Cidadania aprovou o texto final do projeto. Parecer } \\
\text { n. } 221 / 93 \text { do Relator e a emenda à redação do art. } 44 \text {, publicada no DCN (seção II), de } 3 \\
\text { de julho de } 1993 \text {. }\end{array}$ \\
\hline 14.jun.1993 & $\begin{array}{l}\text { Aprovado no Senado, o projeto foi encaminhado para revisão na Câmara dos Deputados } \\
\text { renumerado na Casa para PL } 4 \text { 018/1993. O Relator seria escolhido três meses depois, } \\
\text { o Deputado Mário Chermont da Comissão de Defesa do Consumidor, Meio Ambiente e } \\
\text { Minorias. }\end{array}$ \\
\hline 23.nov.1994 & $\begin{array}{l}\text { Somente } 14 \text { meses depois de escolhido, o Relator na Câmara dos Deputados apresenta } \\
\text { o parecer. }\end{array}$ \\
\hline 14.mar.1995 & $\begin{array}{l}\text { Projeto reencaminhado à Comissão de Defesa do Consumidor, Meio Ambiente e } \\
\text { Minorias com o Deputado Celso Russomano do PSDB como Relator. }\end{array}$ \\
\hline 11.abr.1995 & Fundação da Comissão de Arbitragem da Associação Comercial do Rio de Janeiro. \\
\hline 24.abr.1995 & $\begin{array}{l}\text { Aprovação unânime pelos membros da Comissão de Defesa do Consumidor, Meio } \\
\text { Ambiente e Minorias. }\end{array}$ \\
\hline 11.maio.1995 & $\begin{array}{l}\text { Entregue à Comissão de Constituição e Justiça e de Redação. Relator: Deputado Prof. } \\
\text { Regis de Oliveira. }\end{array}$ \\
\hline 22.maio.1995 & $\begin{array}{l}\text { Fundação da Câmara de Mediação e Arbitragem da Ciesp, coordenada pela Prof. Selma } \\
\text { Maria Ferreira Lemes. }\end{array}$ \\
\hline Dd.maio.995 & $\begin{array}{l}\text { Fundação da Comissão de Arbitragem da Câmara Internacional do Brasil em Belo } \\
\text { Horizonte, Minas Gerais. }\end{array}$ \\
\hline 21.ago.1995 & $\begin{array}{l}\text { I Jornada Brasileira sobre Arbitragem Comercial, como preparação para a XV } \\
\text { Conferência Internacional de Arbitragem Comercial. Presentes: Vice-Presidente da } \\
\text { República Marco Maciel, o Presidente da Confederação das Associações Comerciais do } \\
\text { Brasil, Guilherme Afif Domingos, o Presidente da Associação Comercial do Rio de } \\
\text { Janeiro, Humberto Eustáquio Cesar Mota, o Presidente do Conselho Empresarial das } \\
\text { Relações de Comércio Exterior da ACRJ, Paulo Manoel Protásio e o Presidente da } \\
\text { Comisión Paraguaya de Arbitraje Comercial, Federico Callizo Nicora. Demais presentes: } \\
\text { Cláudio Vianna de Lima, Petronio Gonçalves Muniz, Guido Fernando da Silva Soares, } \\
\text { Guilherme Fernández de Soto, Paulo Manoel Protásio e José Carlos de Magalhães. }\end{array}$ \\
\hline 23.ago.1995 & $\begin{array}{l}\text { Parecer do Deputado Régis de Oliveira (ex-Desembargador do TJRJ) pela } \\
\text { constitucionalidade do projeto. }\end{array}$ \\
\hline Dd.ago.1995 & $\begin{array}{l}\text { Deputado Milton Mendes (PT-SC) apresentou declaração de voto em separado pela } \\
\text { "inconstitucionalidade da presente proposição e, no mérito, pela sua rejeição". }\end{array}$ \\
\hline
\end{tabular}




\begin{tabular}{|ll|}
\hline 26.set.1995 & $\begin{array}{l}\text { Recurso n. 40/95 interposto pelo Deputado Jacques Wagner, líder do PT, requerendo } \\
\text { que a proposição fosse apreciada pelo Plenário. }\end{array}$ \\
\hline Dd.set.1995 & XV Conferência Internacional de Arbitragem Comercial. Assunção, Paraguai. \\
\hline Dd.mm.1995 & $\begin{array}{l}\text { Fundação da Associação Brasileira de Mediadores (Abrame). Fundadores: Ângelo Volpi } \\
\text { Neto, Maria Augusta Volpi e Áureo Simões Júnior. }\end{array}$ \\
\hline 4.out.1995 & O Projeto de Lei levado a plenário recebeu 12 propostas de emendas. Dez de parte do \\
& Dep. Milton Mendes e duas de parte do Deputado Aldo Arantes. \\
& Emendas mais relevantes oferecidas em Plenário, pelo Deputado Milton Mendes (PT- \\
& SC): \\
& - Substituição do termo "sentença arbitral" pela expressão "laudo arbitral". Justificativa: \\
& arbitragem não é órgão do poder Judiciário, e por isso, suas decisões não podem ter os \\
& mesmos efeitos das sentenças judiciais; \\
& - Estipulação de valor minimo para uso da arbitragem em mediações de conflitos: 2 000 \\
& o00 Ufir; \\
& - Supressão do artigo que veda recurso ao poder Judiciário e homologação pelo Juiz. \\
& Arbitros não podem ser considerados "juizes de direito"; \\
& - Inconstitucionalidade da redação que prevê que a decisão arbitral teria os mesmos \\
& efeitos da sentença proferida pelos órgãos do poder Judiciário; \\
& - Supressão do art. 34, que compatibiliza os tratados internacionais; \\
& - É aprovada a emenda substitutiva que prevê a homologação em juizo da sentença \\
arbitral já que a pura supressão do art. 31 do Projeto de Lei que confere à sentença \\
arbitral os mesmos efeitos da sentença do poder Judiciário ocasionaria uma lacuna \\
legal.
\end{tabular}

FONTES: Muniz (2005); Machado (2009). 